\title{
BANK SYARIAH : Antara Labelisasi dan Pemberdayaan Ekonomi Masyarakat
}

\author{
Mansur \\ STAI Miftahul Ulum Pamekasan \\ elcmansur@yahoo.co.id
}

Abstract :

The concept of Syariah Bank empowerment of the community's economy through its products such as: Mudharabah, Musyarakah, Murabahah, Kafala, and others, is a banking service that reflects its concern for improving the economy and welfare of the poor. While the weaknesses in the internal field such as inadequate institutional factors, and external factors, such as the readiness of the community to accept the presence of the Syariah Bank, are welcome in the National banking system, provided they are accompanied by high progression. The labeling of "syariah" in a bank is intended as a banking system in accordance with Islamic Law (Syariah) which is rahmatan lil 'alamin. While the influence of labeling in the context of community economic empowerment is not so significant. Because, there is more needed is the quality of service and ease of access. In addition, the formalization of religion has the potential to be misused by its role to be so particular. In fact, for non-Muslims it is considered a politicaleconomic institution founded on religious sentiments. Thus, the position of Bank Syariah is still ambiguous between community economic empowerment or formalization of religion.

Key word : Empowerment, Formalization, Labeling

\section{Pendahuluan}

Problem kemanusiaan akan selamanya bersentuhan dengan ranah kehidupan yang terus berputar dari masa ke masa. Dalam waktu yang bersamaan upaya pemecahan masalahpun tidak kalah gencarnya menyodok dan mencairkan kebekuan persoalan yang tak pernah tuntas. Antara masalah yanga ada dengan solusi yang tidak pernah rela selalu gayung bersambut, seirama. Namun, hasilnya tidak mampu memuaskan siapapun yang mencoba mencari hipotesisnya secara meyakinkan. Ketika suatu keberhasilan mengemuka, maka disitu pula negasi (peniadaan atas)-nya menampakkan diri. Dua hal yang berlawanan seakan-akan tak pernah bisa dipisahkan garis demarkasi secara tegas.

Di sisi lain, problem bukanlah secercah cahaya yang selalu dinantikan setiap insan. Tetapi anehnya, ia juga tidak pernah surut dari medan kehidupan. 
Kehadirannya dibutuhkan, namun tidak diinginkan. Kemudian, pesan yang timbul adalah kita dipaksa untuk menerima apa adanya, disamping juga diharuskan untuk memilah kemudian dimasukkan ke dalam wahana yang beragam secara proporsional. Hal ini tentu membutuhkan daya kreatifitas yang cerdas dan tidak serampangan mengambil sikap, walau nampak biasa-biasa saja. ${ }^{1}$

Mengedepankan sikap seperti ini bukan berarti meremehkan daya upaya perubahan dalam menegakkan tonggak kebenaran. Justru, antara yang berhasil mengentaskan dan yang belum, menunjukkan prestasi juang yang tidak semua orang mampu melakukannya. Masing-masing berhak mendapatkan anugerah penghargaan yang setimpal.

Itulah kiranya hakikat yang diinginkan alam ini yaitu, pola-pola keseimbangan (moderasi) yang menjadi lahan basah persemaian benih kebijaksanaan untuk mencapai puncak kebahagiaan. Moderasi (wasathiyyah) antara dua hal yang berbeda atau antara dua hal yang bertolak-belakang atau keseimbangan dari selain dua hal tadi. ${ }^{2}$ Untuk meraih kesejahteraan dan kebagiaaan hidup, banyak orang yang beranggapan bahwa ekonomilah faktor penentunya. ${ }^{3}$ Apabila mapan perekonomian keluarga, maka kesejahteraan bisa dipastikan berhasil dinikmatinya. Dengan hidup sejahtera tentu lebih menjamin terwujudnya kebahagiaan. Begitupula dalam kehidupan bernegara tidak akan lepas dari kegiatan ekonomi. ${ }^{4}$

Pusat kegiatan perekonomian yang paling mudah temukan adalah pasar. Sedangkan sarana yang paling efektif dan lebih dikenal masyarakat dalam transaksi adalah uang. Maka, dalam hal ini hanya banklah selama ini menjadi lembaga keuangan yang paling dipercaya menghimpun dan mendistribusikan dana masyarakat. Dalam khazanah keislaman, perbankan islam merupakan lembaga keuangan yang tergolong belia. ${ }^{5}$ Kalau kita kaji perkembangan perbankan islam yang hampir menyamai, bahkan dalam beberapa hal melampaui prestasi perbankan konvensional dewasa ini, tidak mungkin terlepas dari alur pemikiran di atas. Bahwa, aspek positif dan negatif secara beriringan akan terus berpacu melawan waktu. ${ }^{6}$ Pada awal munculnya, perbankan islam lahir sejalan dengan babak baru perkembangan pemikiran mengenai ekonomi islam mengenai dasawarsa 70 -an langsung di tingkat internasional. Faktor yang

${ }^{1}$ D. Juliantara, Memutar Roda Hidup, Memberi Makna pada Hidup, Asia Sedar, Panggungharjo : 2002, Cet. 1, hal.1-2

2 Afifuddin Muhajir, Membangun Nalar Islam Moderat: Kajian Metodologis, (Tanwirul Afkar : Situbondo, 2018) hal. 1-27

${ }^{3}$ Umer Chapra, Islam dan Pembangunan Ekonomi, Gema Insani Perss, Jakarta : 2000, hal. 7

${ }^{4}$ Leslie Stevenson dan David 1. Haberman, Sepulub Teori Hakikat Manusia, Yudi Santoso dan Sart Pasaribu (penerj.), Yayasan Bentang Budaya, Yogyakarta : 2001, Cet. 1, hal. 208

${ }^{5}$ Adimarwan, Ekonomi Islam, Suatu Kjian Kontemporer, Gema Insani Perss, Jakarta : 2001, hal. 66

${ }^{6}$ Al Mannan, Teori dan Praktek Ekonomi Islam, Dana Bakti Primayasa, Jakarta : 1997, hal. 184-186 
membidaninya adalah apa yang disebut dengan kekuatan Petro dollar, artinya dolar yang dihasilkan oleh industri perminyakan. Peningkatan perekonomian suatu bangsa memiliki pengaruh vital terhadap pemberdayaan masyarakatnya. Di samping itu juga karena timbulnya kesadaran tentang "kebangkitan islam pada abad ke-14 Hijriyah" yang melanda dunia islam, serta lahirnya generasi baru intelektual muslim yang mendapatkan pendidikan modern baik di Barat maupun di negara-negara Islam sendiri. ${ }^{7}$

Urgensi pemberdayaan ekonomi masyarakat ini merupakan jawaban --jika bukan sekedar reaksi spontan--- dari masyarakat atas kenyataan sosial ekonomi berupa kesenjangan sosial-ekonomi yang semakin lebar. Kesenjangan yang membawa implikasi sosial, ekonomi, dan politik yang sangat serius terhadap eksistensi Negara Kesatuan Republik Indonesia. Jika tidak segera dicari solusinya. Kesenjangan itu, tidak lain karena diakibatkan pemilikan sumber daya produksi dan produktifitas yang tidak sama diantara pelaku ekonomi, sehingga menghasilkan tingkat kesenjangan yang rendah.

Ada ketidakpuasan di benak para pemikir dan pemuka Islam ketika kesejahteraan mereka terangkat justeru di atas penderitaan saudaranya. Sistem kapitalis yang menggurita telah melahirkan kesenjangan yang menganga lebar. ${ }^{8}$ Sementara, formalisme agama kian gencar disodorkan, bahwa Islam betul-betul agama yang sempurna dan rahmatan lil'alamin.' Dengan simbol-simbol 'islam' atau 'syariah' atau apapun jenis labelnya, sejatinya sikap itu harus menanggung konsekuensi potensi penyimpangan yang cukup besar. Mengedepankan embelembel agama berarti menyimpan bom waktu yang suatu saat nanti bisa saja meledak tanpa disertai kemampuan mencegahnya. Penyematan atribut hansip misalnya, apalagi gampang didapatkan di kios-kios kecil, berarti juga memberi kesempatan kepada yang bukan hansip untuk memakainya pula. Apabila betul itu yang terjadi, akan banyak hansip-hansip gadungan bermunculan tanpa integritas jabatan dan dedikasi yang handal. Maka, itulah yang disebut dengan "senjata makan tuan".

Begitu pula yang akan terjadi dalam perbankan islam (syariah). Kelemahan itu tidak mungkin pergi dan lenyap begitu saja. ${ }^{10}$ Kekurangan itu akan selalu ada, yang menuntut kewaspadaan dan keterbukaan menerima dinamika perkembangan masyarakat. Perbankan islam akan terus diuji jaman, apakah mampu mempertahankan jargonnya : Pemberdayaan ekonomi masyarakat" atau hanya dijadikan 'pemanis' kapitalisme baru.

\footnotetext{
${ }^{7}$ Umer Chapra, Islam dan Pembangunan Ekonomi, Gema Insani Perss, Jakarta : 2000, hal. vii

${ }^{8}$ Umer Chapra, Al Qur'an Menuju Sistem Moneter yang Adil, Dana Bakti Primayasa, Jakarta : 1997, hal. xxiv-xxvii

${ }^{9}$ Mahmud, Garis-garis Besar Ekonomi Islam, Gema Insani Press, Jakarta : 1992, hal. 15

${ }^{10}$ Adimarwan, Ekonomi Islam, Suatu Kajian Kontemporer, Gema Insani Perss, Jakarta : 2001, hal. 83-85
} 


\section{Upaya Bank Syariah Dalam Pemberdayaan Ekonomi Masyarakat}

Selaras dengan kehadiran bank syariah di tengah-tengah sistem perbankan konvensional yang telah mendunia dengan umurnya yang sangat tua dalam peradaban manusia, sangatlah layak jika banyak pihak masih dalam sikap keraguan bahkan banyak yang tidak paham apa itu bank syariah. Bank syariah tidak dapat dipisahkan dari gagasan yang lebih luas, yakni ekonomi-islam. Gagasan mengenai ekonomi-islam dan bank syariah adalah hasil pengembangan pemikiran ideologis ke pemikiran ilmiah, tetapi tidak bermuatan politis. Khusus di Indonesia, gagasan untuk mendirikan Bank Syariah, sebagai istilah pengganti Bank Islam ---istilah tersebut terakhir dihindari karena bersifat ideologis--sebenarnya telah muncul sejak 1923 pleh Haji Oemar Said Tjokroaminoto dalam bukunya yang berjudul Sosialisme Islam. Bahkan dari karangan Bung Hatta dapat diketahui bahwa sebelum zaman pergerakan kemerdekaan telah berdiri Bank Syariah yang mengganti bunga bank dengan istilah " biaya adminitrasi". 11

Gagasan tersebut tidak lepas dari kajian keagamaan tentang hukum bunga bank dan riba di kalangan cendekia muslim kontemporer atau yang klasik, baik yang ada di organisasi keagamaan maupun kalangan perbankan dan perorangan. ${ }^{12}$ Adalah KH. Mas Mansur, Pengurus Muhammadiyah pada tahun 1937 berkeinginan mendirikan bank Syariah. Namun gagal, karena dianggap berbau SARA pada saat itu dan dikhawatirkan mengganggu stabilitas nasional. ${ }^{13}$ Perdebatan mengenai hukum bungan bank tersebut menunjukkan bahwa sebenarnya secara obyektif masyarakat membutuhkan lembaga keuangan pinjam-meminjam yang betul-betul tidak dipersoalkan lagi keberadaannya, terutama dalam dunia modern untuk pengembangan usaha dan pembangunan. Jadi, dengan berdirinya bank syariah bisa dijadikan jawaban konkrit pada pemahaman kebanyakan ulama bahwa riba itu haram. Sedangkan bank itu sendiri halal, asalkan tidak mempraktikkan sistem yang berdasarkan riba. Dengan demikian, maka bank syariah merupakan alternatif terhadap bank konvensional. ${ }^{14}$

Ide Bank Syariah mencuat lagi kepermukaan pada pertengahan tahun '70-an. Hal ini dibicarakan, umpamanya, pada seminar hubungan IndonesiaTimur Tengah pada tahun 1974 (seminar nasional) dan tahun 1976 (seminar internasional) oleh lembaga Studi Ilmu-ilmu Kemasyarakatan (LSIK) dan

${ }^{11}$ M. Umer Chapra, Islam dan Tantangan Ekonomi, Islamisasi Ekonomi Kontemporer, Tim Risalah Gusti (penerj.), Risalah Gusti, Surabaya, : 1999, Cet. 1, hal vii

12 Zainal Abidin, Negara Adil Makmur Menurut Ibnu Siena, Bulan Bintang, Jakarta : 1974, Cet. 1, hal 273

${ }^{13}$ Rachmadi Usman, Aspek-aspek. Hukum Perbankan Islam di Indonesia, PT. Citra Aditya Bakti, Bandung : 2002, Cet. 1, hal. 83

${ }^{14}$ Insiklopedi Islam, PT. Ichtiar Baru Van Hoeve, Jakarta : 2002, Cet. 1, hal. 400 
Yayasan Bhinneka Tunggal Ika. Ada beberapa alasan yang menghambat lajunya ide tersebut. ${ }^{15}$

Pertama, karena operasi Bank Syariah yang menerapakan prinsip bagi hasil (Profil and Loss Sharing Pronciple) itu belum diatur dan karena itu tidak sejalan dengan UU pokok Perbankan yang berlaku, yakni UU nomor 14 Tahun 1967. Kedua, konsep Bank Islam, sebutan waktu itu, terjemahan dari atau berkaitan dengan konsep negara islam, dan karena itu tidak dikehendaki oleh pemerintah. Ketiga, masih dipertanyakan, siapa yang bersedia menaruh, modal dalam bentuk ventura, semacam itu, sementara pendirian bank baru yang berasal dari Timur Tengah konon masih dicegah, antara lain, karena pembatasan bank asing yang ingin membuka kantornya di Indonesia. ${ }^{16}$

Walhasil, gagasan itu tenggelam untuk sementara waktu. Tapi, sejak terjadi krisis dan pembiyaan pembangunan oleh pemerintah mulai tahun 1982 --karena resesi perekonomian dunia, merosotnya harga minyak bumi dan keterbatasan dalam masalah utang luar negeri--- menurut pemerintah agar mengikutsertakan peran serta masyarakat. Melalui paket kebijakan pada tanggal 27 Oktober 1988 (pakto 1988), yaitu paket deregulasi di bidang keuangan, moneter dan perbankan. Sasaran kebijaksanaan tersebut di antaranya untuk meningkatkan pengerahan dana masyarakat, yang ada gilirannya akan meningkatkan pertumbuhan ekonomi yang cukup tinggi serta perluasan kesempatan kerja, termasuk kemungkinan pendirian dan usaha bank-bank baru. Dengan demikian pemerintah mau harus mempertimbangkan kembali kehendak umat islam untuk mendirikan bank Syariah. ${ }^{17}$

Pada akhir '80-an, timbul upaya-upaya ---khususnya dari Majelis Ulama Indonesia (MUI)--- untuk menghidupkan kembali gagasan Bank Syariah. Melalui seminar pada tahun 1989 yang mengundang unsur pemerintah dan Bank Indonesia terdengar pendapat, bahwa Bank yang beroprasi menurut sistem syariah dimungkinkan pendirinya. Padahal belum ada undang-undang baru yang mengaturnya. Salah satu alasan teoritis bahwa bank syariah tidak bertentangan dengan UU yang berlaku, khususnya dalam aspek sistem bunga, karena bank syariah memakai sistem bunga "nol Persen". Tentu saja ini alasan yang dicaricari untuk memberikan legitimasi pendirian suatu lembaga keuangan yang

\footnotetext{
${ }^{15}$ M. Dawam Raharjo, Islam dan Transpormasi Sosial- Ekonomi, Lembaga Studi Agama dan Filsafat, Jakarta : 1999, Cet.1, hal. 404

${ }^{16}$ Ibid, hal. 405

17 Muhammad, Bank Syariah: Analisis Kekuatan, Kelemahan, Peluang dan Ancaman, Ekonisasi, Yogyakarta : 2002, Cet. 1, hal. 21, 65, 72; Rachmadi Usman, Aspek-aspek Hukum Perbankan Islam di Indonesia, PT. Citra Aditya Bakti, Bandung : 2002, Cet. 1, hal 92; dan Ibid, hal.405
} 
mampu menghimpun dana dari masyarakat, yang sejalan dengan iklim deregulasi. $^{18}$

Prakarsa lebih khusus lagi untuk mendirikan bank syariah, baru dilakukan pada tahun 1990. Majelis Ulama Indonesia (MUI) pada tanggal 18-20 Agustus 1990 menyelenggarakan lokakarya Bunga Bank dan Perbankan di Cisarau, Jawa Barat. Hasil lokakarya tersebut dibahas lebih dalam lagi pada Musyawarah Nasional IV MUI yang berlangsung di Hotel Sahid Jaya Jakarta, 22-25 Agustus 1990. Berdasarkan amanat Munas MUI, dibentuk kelompok kerja untuk mendirikan bank islam di Indonesia. ${ }^{19}$

Semua ketidakpahaman itu tidak bisa dilepaskan dari asal munculnya gagasan bank syariah yang digali dari ide yang spektrumnya lebih luas, yaitu ekonomi islam. Sementara, wacana ekonomi islam sendiri masih menyimpan perdebatan ketika memasuki wilayah konsep. Sebagaimana hasil penelusuran penulis, bahwa ekonomi islam Paling tidak ada 3 madzhab, yaitu Madzhab Baqir as-Sadr, Madzhab Mainstream dan Madzhab Alternatif-Kritis. Dengan begitu, pohon gagasan bank syariah tumbuh dari akar pemikiran yang bias, maka akan meniscayakan buah produk bank syariah tidak mudah dikenal ketika dibandingkan dalam realitas masyarakat.

Madzhab Baqir as Sadr, diolopori oleh Muhammad Baqir as Sadr dengan bukunya yang fenomenal : Iqtishaduna (ekonomi kita). Bagi madrhab ini, ilmu ekonomi tidak pernah bisa sejalan dengan Islam. Ekonomi tetap ekonomi, dan islam tetap Islam. Keduanya, tidak akan pernah dapat disatukan, karena keduanya berasal dari filosofi yang saling kontradiktif. Yang satu anti islam, sedang yang lainnya pro islam. ${ }^{20}$ Madzhab Baqir menolak pernyataan, "bahwa masalah ekonomi muncul karena adanya keinginan manusia yang tidak terbatas sementara sumber daya yang tersedia untuk memuaskan keinginan manusia tersebut jumlahnya terbatas”. Karena menurut mereka, islam tidak mengenal adanya sumber daya yang terbatas. Dalil yang dipakai adalah surat al Qamar ayat 49 yang artinya: "Seseunggubnya kami menciptakan segala sesuatu menurut ukuran (yang setepat-tepatnya)". ${ }^{21}$

Dengan demikian, karena segala sesuatu sudah terukur dengan sempurna, berarti Allah telah memberikan sumber daya yang cukup bagi seluruh manusia di dunia. Masalah ekonomi muncul karena adanya distribusi yang tidak

${ }^{18}$ M. Dawam Raharjo, Islam dan Transpormasi Sosial- Ekonomi, Lembaga Studi Agama dan Filsafat, Jakarta : 1999, Cet.1, hal. 405-406

${ }^{19}$ Muhammad Syafi'i Antonio, Bank Syari'ah : Dari Teori ke Praktek, Gema Insani Press, Jakarta : 2001, Cet. 1, hal. 25

${ }^{20}$ Adiwarman, Sejarah Pemikiran Ekonomi Islam, Tim IIT (penerj.), , the International Institute os Islamic Thought (IIIT) Indonesia, 2002, Cet . 2, hal. 13-14

${ }^{21}$ Departeman Agama, Al Qur'an dan Terjemahannya, Yayasan Penyelenggara Penterjemah Al Qur'an, PT. Bumi Restu, Jakarta : 1975, hal. 883 
merata dan adil. Akibat sistem ekonomi yang memperbolehkan eksploitasi pihak yang lemah. Jadi bukan karena persoalan sumber daya yang terbatas, tetapi karena keserakahan manusia yang tidak terbatas.

Sebab itu pula mereka tidak setuju dengan istilah "ekonomi Islam". Istilah tersebut bukan hanya tidak sesuai dan salah, tapi juga menyesatkan dan kontradiktif. Istilah yang ditawarkan diambil dari filosofi Islam, yakni iqtishad. Menurut mereka, "iqtishad" bukan sekedar terjemahan dari kata "ekonomi", melainkan berasal dari bahasa Arab "qasd" yang secara harfiyah berarti "ekuilibrium" atau keadaan sama, seimbang atau pertengahan.

Madzhab Mainstream, bertolak belakang dengan madzhab Baqir. Madzhab kedua ini justeru setuju masalah ekonomi muncul karena sumberdaya yang terbatas ketika diperhadapkan dengan keinginan manusia yang tidak terbatas. Argumen mereka, memang benar misalnya, total dan permintaan bebas di seluruh dunia pada titik ekulibrium. Namun, jika kita bicara menyungkut persoalan tempat dan waktu tertentu, maka sangat mungkin terjadi kelangkaan sumber daya. Bahkan ini yang sering terjadi. Suplai beras di Ethiopia dan Bangladesh misalnya, tentu lebih langka dibanding dengan di Thailand. Jadi keterbatasan sumber daya memang ada, bahkan diakui pula oleh Islam. Dalil yang dipakai oleh mereka, surat al Baqarah ayat 155, yang artinya : "dan sungguh akan kami berikan cobaan kepadamu, dengan ketakutan, kelaparan, kekurangan harta, jiwwa dan buab-buahan. Dan berikanlab berita gembira kepada orang-orang yang sabar". ${ }^{22}$

Sedangkan keinginan manusia yang tidak terbatas dianggap sebagai hal yang alamiah. Dalilnya, Surat al Takasur ayat 1-4, yang artinya : "Bermegahmegahan telah melalaikan kaum. Sampai kamu masuk. ke dalam kubur. Janganlah begitu, kelak kamu akan mengetabui (akibat perbuatan itu)". ${ }^{23} J a d i$ kelangkaan sumber dayalah yang menjadi penyebab munculnya masalah ekonomi. Bila demikian, dimanakah letak perbedaan dengan ekonomi konvensional?.

Perbedaan terletak pada cara menyelesaikan masalah tersebut. Karena, ketika dilema keinginan tak terbatas membentur sumberdaya yang terbatas, maka kemudian manusia menyusun skala prioritas pemenuhan keinginan, dari yang paling penting sampai dengan yang paling penting. Dalam ekonomi konvensional, pilihan dan menentukan skala prioritas dilakukan berdasarkan selera pribadi masing-masing. Manusia boleh mempertimbangkan tuntutan agama, ataupun mengabaikannya. Tetapi dalam ekonomi islam, keputusan pilihan tidak boleh dilakukan semuanya saja. Perilaku manusia dalam setiap

\footnotetext{
${ }^{22}$ Ibid, hal. 39

${ }^{23}$ Ibid, hal. 1096
} 
aspek kehidupan ---termasuk ekonomi--- selalu dipandu oleh Allah melalui al Qur'an dan al Hadits. ${ }^{24}$

Yang terakhir, Madzhab Alternatif-Kritis. Pelopor madzhab ini adalah Timur Kuran (ketua jurusan ekonomi di University of Southern California), Jomo (Yale, Cambidge, Harvard, malaya), Muhammad Arif dan lain-lain. Madzhab ini mengkritik kedua madzhab sebelumnya. Madzhab Baqir dikritik sebagai madzhab yang berusaha untuk menemukan sesuatu yang baru yang sebenarnya sudah ditemukan oleh orang lain. Menghancurkan teori lama, kemudian menggantinya dengan teori baru. Sementara madz̧ $a b$ Mainstream dikritik sebagai jiplakan dari ekonomi neo-klasik dengan menghilangkan variabel zakat serta niat.

Madzhab ini adalah sebuah madzhab yang kritis. Mereka berpendapat bahwa analisis-kritis bukan saja harus dilakukan terhadap sosialisme kapitalisme, tetapi juga terhadap ekonomi-islam itu sendri. Mereka yakin Islam pasti benar, tetapi ekonomi islam belum tentu benar karena ekonomi-islam hasil tafsiran manusia atas al Qur'an dan As Sunnah sehingga nilai kebenarannya tidak mutlak. Proposisi dari teori yang diajukan oleh ekonomi-islam harus selalu diuji kebenaraannya sebagaimana yang dilakukan terhadap ekonomi konvensional. ${ }^{25}$

Walaupun begitu, di Indonesia bank syariah juga mendapat sambutan meriah, yang sejak kemunculannya pada tahun 1992 hingga Mei 2003 jumlah jaringan bank syariah mencapai 116 kantor cabang dan 87 Bank Perkreditan Rakyat Syariah (BPRS) yang tersebar di 20 Provinsi. Sedangkan dana yang Berhasil dihimpun dari pihak ketiga (nasabah dan mitra usaha), hingga akhir Maret 2003 mencapai 3,32 triliun. ${ }^{26}$ Ini merupakan capaian yang cukup mencengangkan. Bandingkan dengan data Otoritas Jasa Keuangan ( $\underline{\mathrm{OJK}})$ per Februari 2017, total asset keuangan syariah (tidak termasuk saham syariah) mencapai Rp 897,1 triliun atau 67,21 miliar dollar AS (kurs 13.347). ${ }^{27}$

${ }^{24}$ Adiwarman, Ekonomi Mikero Islam, the International Institute os Islamic Thought (IIIT) Indonesia, 2002, Cet. 1, hal. 16

${ }^{25}$ Adiwarman, Ekonomi Mikro Islam, the International Institute os Islamic Thought (IIIT) Indonesia, 2002, Cet. 1, hal.16

${ }^{26}$ Kompas,31 Mei 2003

${ }^{27}$ Dari total aset keuangan syariah tersebut, proporsi pasar modal syariah mencapai 50 persen atau sebesar Rp 451, triliun atau sekitar 32,82 miliar. Setelah pasar modal syariah, kontribusi terbesar aset keuangan syariah berasal dari industri perbankan syariah dengan proporsi mencapai 40 persen atau sebesar Rp 355,9 triliun atau 27,39 miliar dollar AS. Sementara itu, Industri Keuangan Non-Bank (IKNB) syariah yang meliputi asuransi syariah, pembiayaan syariah, lembaga nonbank syariah lainnya hanya 10 persen atau sebesar Rp 90,08 triliun atau 6,64 miliar dollar AS. Sampai pekan ketiga April, ada 45 manajer investasi yang mengelola reksa dana syariah, dan 14 bank kustodian yang telah memperoleh rekomendasi DSN-MUI untuk memberikan layanan syariah. Jumlah perusahaan sekuritas yang menjadi penjamin emisi dalam penerbitan sukuk korporasi di Indonesia mencapai 22 perusahaan, dengan enam wali amanat 
Perkembangan yang pesat tersebut sekaligus menjawab pemahaman kebanyakan ulama bahwa riba itu haram. Selain itu, bank syariah memang sangat dibutuhkan oleh masyarakat sebagai solusi dari problem sistem perbankan konvensional yang dianggap kurang humanis. Tak jarang bila seorang nasabah mengalami kerugian usaha, maka tanpa ampun pihak bank akan menyita barang jaminannya, termasuk tempat tinggal dan tanah sekalipun.

Di sini pulalah letak perbedaan mendasar antara bank syariah dan konvensional yang berorientasi pada kehidupan dunia, kini dan disini, tetapi sekaligus pada kehidupan akhirat, nanti dan disana, sehingg ada rasa kepuasan tersendiri bagi nasabah, baik bersifat duniawi maupun ukhrawi.

Faktor lain keunggulan sistem syariah, karena bank syariah selalu mengaitkan antara sektor riil dan sektor financial, serta menjadikan sektor riil sebagai lokomotifnya. Tidak heran jika hingga Maret 2003, pembiayaan sektor untuk UMKM (Usaha Makro Kecil dan Menengah) mencapai 90 persen dari total pembiayaan perbankan syariah sebesar Rp 3,66 triliun.

Mengembangkan konsep interdependensi atau saling ketergantungan juga dijadikan pijakan operasional perbankan syariah dengan cara melibatkan partisipasi masyarakat secara langsung dalam pembangunan nasional (good governance) merupakan cita-mulia sebagai agenda reformasi yang tidak semua lembaga mampu melakukan dan memang tidak mudah ditegakkan.

Kegelisahan masyarakat dalam menghadapi kebutuhan modal usaha dan ketenangan investasi (misalnya, masalah bunga bank), sementara lembaga keuangan yang ada kebanyakan menimbulkan kesepahaman yang berbeda, merupakan momen yang tepat bagi tumbuh dan pesatnya perbankan dengan sistem syariah. Jasa perbankan syariah — yang sebagian orang menuduhbanyak "mengadopsi" dari jasa perbankan konvensional, namun ada salah satu produk yang sama sekali beda, yaitu produk Al Qadbu al Hasan, yaitu pinjaman lunak bagi pengusaha yang benar-benar kekurangan modal. Nasabah tidak perlu membagi keuntungan kepada bank, tetapi hanya membayar biaya adminitrasi

dalam penerbitan sukuk. Ada 10 pihak penerbit Daftar Efek Syariah. Sementara itu mengenai pertumbuhan saham syariah bertambah satu menjadi 348 saham dibanding 347 saham pada 2016. Kapitalisasi saham syariah tercatat sebesar Rp 3.408,04 triliun atau tumbuh 9,25 persen dibandingkan 2016 yang sebesar Rp 3.119,42 triliun. Sedangkan jumlah reksa dana syariah bertambah sembilan menjadi 145 reksa dana dari 136 reksa dana pada 2016. Adapun NAB atau nilai aktiva bersih tercatat sebesar Rp 18,16 triliun atau tumbuh 21,8 persen dibandingkan 2016 yang sebesar Rp 14,91 triliun. Jumlah sukuk korporasi outstanding per 21 April sebanyak 55 seri dengan nilai Rp 12,13 triliun atau naik 2,1 persen dibandingkan akhir 2016 sebesar Rp 11,88 triliun. Adapun jumlah sukuk negara outstanding sebanyak 53 seri dengan nilai mencapai Rp 485,8 triliun atau meningkat sebesar 18,09 persen dibandingkan akhir 2016 yang sebesar Rp 411,37 triliun. Hal ini merupakan sukuk negara terbesar di dunia saat ini, dengan pertumbuhan 18,09 persen. http://ekonomi.kompas.com/read/2017/04/28/173602626/februari.2017.aset.industri.keuan gan.syariah.capai.rp.897.1.triliun 
saja. Tentu saja jenis pinjaman ini beda dengan istilah "kredit lunak" pada bank konvensional. Hal ini juga mencerminkan kepedulian perbankan syariah pada nasib pengusaha kecil.

Namun begitu, perbankan dengan sistem syariah tidak luput dari kelemahan-kelemahan. Seperti dilaporkan dalam survei Masyarakat Ekonomi Syariah (MES) lebih banyak disebabkan adanya kesalah pahaman masyarakat akan konsep dan penerapan ekonomi syariah. Survei tersebut dilakukan di beberapa daerah anatara lain : Jawa Barat, Jawa Tengah, DIY, Jawa Timut, Sumatra dan Jambi. Selain itu jaga karena faktor lemahnya institusi lembaga keuangan dan tidak adanya undang-undang serta peraturan sejenis yang mendukung penuh penerapan konsep ini. Penulis sepakat dengan apa yang diuraikan Adiwarman A. Karim, mengenai kelemahan bank syariah, yang terletak pada :

- Mekanisme kontrol. Selama ini audit terhadap bank syariah dilakukan oleh Bank Indonesia, bukan Dewan Syariah Nasional yang ada, yang salah satunya berfungsi mengawasi bank syariah.

- Lemahnya transportasi bank syariah. Misalnya menyangkut persentase bagi hasil. Harus ada penjelasan, misalnya, mengapa bank syariah hanya bisa memberikan 'bunga' 10 persen, sementara bank konvensional bisa memberikan bunga hingga 17 persen. Adiwarman menambahkan, "bank syariah berlindung di belakang istilah bagi hasil, padahal harus ada penjelasannya".

- Kesigapan bank syariah dalam memanjakan nasabah juga masih payah. Misalnya, mesin ATM (anjungan tunai mandiri) yang jumlahnya sangat terbatas. Karena minimnya fasilitas itu, nasabah sulit sekali mengambil duit koran sewaktu-waktu.

- Jasa-jasa perbankan masih terbatas. Jasa rekening koran dan kartu kredit, misalnya, belum tersedia di bank syariah.

Dari beberapa kelemahan di atas, “Ada 'tuduhan' sebagai masarakat perihal 'kemurnian' bank syariah yang beroperasi saat ini. Ini memang bisa menimbulkan perdebatan yang panjang dan melelahkan. Tapi mungkin tuduhan itu ada benarnya, tetapi ini menyangkut sistem ekonomi makro perbankan nasional yang memang tidak mudah direvisi. Keberatan yang diajukan anggota masyarakat adalah prihal keterlibatan bank syariah dalam transaksi keterlibatan dengan bank konvensional yang masih berdasarkan riba. Sekedar contoh, adalah wajib bagi sebuah bank untuk mempunyai jaminan di Bank Indonesia (BI) Dana tersebut 'dihargai' oleh BI dengan prinsip bunga ini berarti akan terjadi pencampuran dana yang muncul akibat adanya bunga dengan apa yang dihasilkan oleh operasi bank syariah. Sebab bila tidak, pada kasus PT. BPRS yang berlokasi di kota, Semarang tidak terdapat BPRS atau bank syariah lainnya, 
maka bank tersebut akan kesulitan 'memanfaatkan' kelebihan likuiditas, dan besar kemungkinan akan menanggung rugi.

Mungkin juga, karena adanya indikasi, bahwa manajemen beberapa BPRS, entah terpaksa atau tidak, melakukan transaksi yang sangat berbau riba. Hal ini mengajak masyarakat untuk menghindarkan diri dari riba, sementara pihak yang mengajak tidak bersih dari riba. Tentu saja dari sekian kelemahan itu perbankan syariah indonesia memiliki potensi-potensi yang bisa dikembangkan, yaitu jumlah penduduk muslim yang luar biasa besar. Pemanfaatan kekuatan ini apabila disertai formalisme dan fanatisme agama, seperti yang telah disinggung sebelumnya sebagai sasaran utama bank syariah dalam peningkatan ekonomi, maka justru menjadi kelemahan dan kendala yang serius. Sebab, masalah yang muncul adalah kesenjangan sosial yang berdampak pada dominasi tunggal yang pada gilirannya akan merusak citra Islam sendiri yang diyakini sebagai agama yang rahmatan lil 'alamin.

\section{Pertautan Labelisasi Dengan Pemberdayaan Ekonomi Masyarakat}

Ketika di depan disuguhi teks ataupun buku, akan muncul dibenak kita, siapakah sesungguhnya subyek yang berbicara dan obyek yang hendak disapa oleh teks itu ? Atau, lebih baik mana setelah teks itu selesai dikarang oleh penulisnya, kita anggap otonom atau tetap milik pengarang. Misalnya, menjadi milik pengarang, haruskah itu bertanggung jawab penuh. Dan, kalau menjadi milik publik, betulkah teks itu bisa dipahami secara bebas oleh pembaca ? Maka layak terlebih dahulu kita bahas tentang arti kata (teks) syariah.

Teks adalah aspek statis yang bersifat mengatur, yang terletak di balik wacana syariah. Dengan istilah lain, teks "syariah" adalah fiksasi atau pelembangan dari sebuah peristiwa wacana lisan dalam bentuk tulisan. Teks juga bisa kita artikan sebagai "seperangkat tanda yang ditransmisikan dari seorang pengirim kepada seorang penerima melalui medium tertentu dan dengan kodekode tertentu".

Kata "Syariab" pada mulanya diartikan sebagai "tugas umat manusia yang menyeluruh", meliputi moral, teologi dan etika pembinaan umat, aspirasi spiritual, ibadah formal dan ritual yang rinci. Syariah mencakup semua aspek hukum publik dan perorangan, kesehatan, bahkan kesopanan dan akhlaq. Apabila menganggap ada bagian Syariah yang tidak memadai, akan dituduh bid'ah oleh mayoritas umat islam yang meyakini bahwa keseluruhan syariah itu bersifat ilabiyyah.

Secara gamblang, istilah syariah bisa disebut sebagai Hukum Islam. Hukum Islam sendiri yang berupa wahyu bisa dikatakan syari'at islam, sedangkan hukum islam yang merupakan hasil ijtihad manusia disebut figh atau yurisprudensi Islam. Namun, perkembangan selanjutnya, ketika menyebut kata syariah berarti yang dimaksud adalah figh. Dengan menampilkan makna awal 
"syariah", penulis ingin menyingkap makna di balik kata tersebut dalam sistem tanda. Ada ideologi apa sebenarnya. maksud tanda di sini adalah sesuatu yang merujuk kepada sesuatu yang lain. Ilmu yang mempelajarinya disebut dengan semiologi atau semiotik : ilmu tanda. ${ }^{28}$ Yaitu, bagaimana memahami sistem tanda yang ada dalam teks yang berperan membimbing pembacanya agar bisa menangkap pesan yang terkandung di dalamnya. Dengan ungkapan ini, semiologi bertugas untuk melakukan interogasi terhadap kode-kode yang dipasang oleh penulis agar pembaca bisa memasuki bilik-bilik makna yang tersimpan dalam sebuah teks. ${ }^{29}$ Ketika kata (teks) menjadi tanda, karena dia memiliki signifier (kata itu sendiri) di jadikan label (gelar, nama) suatu lembaga keuangan (seperti bank) sebagai signified (tempat nyata dimana kita dapat memperoleh jasa financial) diharapkan oleh pemberi label, ada pemahaman bahwa bank pengguna label "Syariah" tersebut sistem operasinya sesuai atau memang menerapkan ajaran-ajaran Islam secara benar. Apabila upaya tersebut gayung bersambut, maka muncullah image kalau bank yang berlabel "syariah" adalah bank yang "baik dan benar", sedangkan yang lain (bank konvensional) "menyimpang".

Dalam konteks Indonesia, sejak sebelum zaman kemerdekaan hingga dekade 90-an, penggunaan kata syariah pada sebuah bank, sejatinya merupakan penghindaran dari pemakaian kata "islam" yang ketika itu berbau ideologis. Saat ini pelabelan kata tersebut sejak akhir 90-an hingga sekarang (tahun 2018) menjadi berbau ideologis juga. Karena, selama masa itu isu formalisme agama muncul kembali yang puncaknya pada perjuangan pencantuman kembali tujuh kata yang dibuang pada UUD 1945. Akibatnya, kalangan nasionalis dan nonmuslim sangat keberatan karena dianggap mengancam stabilitas dan keutuhan berbangsa dan bernegara yang heterogen dan multikultural.

Penunjukan (signification) makna (denotasi) syariah yang semula berarti Hukum Islam (figh), kemudian menjadi makna (konotasi) "lain" ketika menjadi label sebuah bank, seperti : tempat investasi yang aman, atau bank yang diridhai Tuhan, atau bank syurga dan sebagainya, dalam ilmu semiotika adalah hal yang wajar dan memang tidak bisa dielakkan. Karena, disamping sifat bahasa yang arbiter (asal-asalan) dan konvensional, makna suatu tanda (sign) juga tergantung pada siapa yang mengartikannya. Tanda menjadi mandiri tanpa tergantung pada tanda-tanda lain. Hanya saja, makna yang terlalu jauh dari makna asal dan tidak konvensional cenderung "dijauhi” oleh pemakai bahasa yang lain. Di sinilah peran 'relasi-relasi kuasa' menentukan nasib makna bahasa yang tersebut. Siapa yang kuat, maka ia akan mendominasi pemaknaannya. Dan, begitu seterusnya

${ }^{28}$ Komaruddin Hidayat, Memahami Bahasa Agama, Sebuah Kajian Hermeneutik, Paramadina, Jakarta : 1996, Cet. 1, hal. 2

${ }^{29}$ Ibid, hal. 163 
silih berganti. Jadi, hubungan keduanya bersifat simbolik, yaitu hubungan tanda dengan dirinya sendiri (hubungan internal antara signifier dan signified). Jadi, sahsah saja tanda "Syariah" dipergunakan (signication) untuk apa saja.

Namun, yakin di balik labelisasi "syariah" dan tujuan lain yang sulit ditebak apa sebenarnya yang diinginkan oleh subyek pemberian label tersebut. Maka tepat sekali apa yang dihasilkan dari penelitian "Potensi, Refrensi dari Perilaku Masyarakat Terhadap Masyarakat Bank syariah Di pulau Jawa" oleh Bank Indonesia per Desember 2000, bahwa faktor yang paling dominan memotivasi masyarakat untuk menggunakan jasa perbankan syariah adalah faktor kualitas pelayanan dan kedekatan lokasi bank dari pusat kegiatan. Sedangkan faktor pertimbangan keagamaan (yaitu masalah halal/ haram) bukanlah faktor penting dalam mempengaruhi kecendrungan menggunakan jasa bank syariah. Namun, untuk masyarakat Jawa Tengah, faktor pertimbangan agama adalah motivator terpenting.

Bank syariah diyakini sebagai bank islami. Tetapi, kata "syariah" bagi masyarakat Jawa Timur, dianggap sebagai nama sebuah bank. Seperti Bank IFI, Bank Mandiri, Bank Jabar dan sebagainya. Bagi kalangan non-muslim, di samping mereka tidak tahu apa itu bank syariah, ada sebagian yang menafsirkan bank syariah merupakan alat politik untuk menghancurkan ekonomi nonmuslim. Bagi mereka, bank syariah adalah sebuah lembaga ekonomi-politik yang didirikan atas dasar sentimen agama dengan tujuan membela salah satu agama. Jadi, yang paling dibutuhkan masyarakat Jawa pada umumnya dan Jawa Timur pada khususnya, bukanlah embel-embel agama, tetapi mutu pelayanan yang praktis, efisien dan humanis. Dengan kata lain, bank syariah harus lebih manusiawi dari pada bank konvensional.

Celakanya, apabila makna "syariah" diartikan sebagai label "pelaris" barang komoditi, ketika label syariah "ditempatkan" pada suatu barang atau lembaga, maka bisa dipastikan akan menjadi rebutan "konsumen". Apa yang akan terjadi ? Dengan mata telanjang akan kita saksikan label "syariah" bertebaran di pasar, kawasan pertokoan dan pusat kegiatan masyarakat lainnya. Mungkin, berupa "warnet syariah", "tape syariah", "becak syariah", "ojek syariah", "sabun syariah", "pasar syariah", "lipstik syariah", "super market syariah", "diskotik syariah", atau juga "goyang-dangdut syariah".("Sadis ?’). Mungkin, hal-hal inilah yang terlupakan oleh Hizbut Tahrir Indonesia, yang dengan gagahnya menyerukan isu "selamatkan Indonesia dengan syariah". Sebab, beresiko memunculkan anggapan negatif dalam sejarah bahwa "syariah adalah militanisme", "syariah adalah kegagalan ekonomi". Menonjolkan simbol atau formalisme agama tidak lebih selamat dari pada mengutamakan substansi ajaran agama. Boleh saja perbankan islam menggunakan label syariah, akan tetapi tetap teguh dalam memperjuangkan jargon "pemberdayaan ekonomi masyarakat". 
Walaupun begitu, dengan bahasa, sebagai sistem tanda (termasuk pemberian label "syariah"), seseorang bisa berjaya, pun dengan bahasa bisa terpedaya. Pertanyaan yang timbul adalah : Apakah penggunaan bahasa lalu tidak dibutuhkan?

Ingat, bahasalah yang membedakan manusia dari dunia hewan. Bahasa telah memungkinkan manusia keluar dari dunia insting ke dunia refleksi dan makna. Barangkali saja, inilah yang diisyaratkan al Qur'an surat al Baqarah (1 : 31), bahwa Allah SW'T. telah mengajarkan pada Nabi Adam segala nama-nama (al asma' ) benda ketika Nabi Adam turun (muncul ?) di muka bumi untuk membangun peradaban. Untuk bisa menghargai betapa vitalnya "nama" dalam kehidupan, cukuplah dengan membayangkan bagaimana kehidupan sosial akan berlangsung kalau saja manusia dan benda-benda tidak memiliki nama.(....)

\section{Penutup}

Telaah teks pada labelisasi syariah pada bank dengan menggunakan analisis semiotik, maka dapat ditemukan beberapa kesimpulan sebagai berikut:

Pertama, konsep pemberdayaan Bank syariah terhadap ekonomi masyarakat melalui produk-produknya seperti : Mudharabah, Musyarakah, Salam, Istisna', Ijarah, Murababah, Al Qardbu al Hasan, Wakalah, Kafalah, Rahn dan lainlain, merupakan jasa pelayanan perbankan yang mencerminkan kepeduliannya kepada peningkatan perekonomian dan kesejahteraan masyarakat terutama kepada pengusaha kecil. Sedangkan kelemahan-kelemahan di bidang internal seperti faktor institusi dan yuridis yang belum memadai, dan faktor eksternal, seperti kesiapan masyarakat menerima kehadiran bank syariah, adalah hal yang lumrah bagi lembaga keuangan yang masih "baru lahir" dalam sistem perbankan nasional, asalkan disertai dengan semangat progresifitas yang tinggi.

Kedua, pemberian label (labelisasi) "syariah" pada sebuah bank dimaksudkan sebagai orientasi sistem perbankan yang sesuai dengan Hukum Islam (Syariah) yang nyata-nyata membela kepentingan manusia seluruhnya (universal). Sedangkan pengaruh labelisasi tersebut dalam konteks pemberdayaan ekonomi masyarakat tidak begitu signifikan. Karena, ada yang lebih dibutuhkan dari pada formalisasi agama, yaitu kualitas pelayanan dan kemudahan mengaksesnya. Di samping itu, formalisasi agama selalu berpotensi untuk disalahgunakan peranannya yang semula universal menjadi begitu partikular. Bahkan labelisasi "syariah" itu, di kalangan non-muslim dianggap sebagai lembaga ekonomi-politik yang didirikan atas dasar sentimen agama dengan tujuan membela salah satu agama. Dengan begitu, posisi bank syariah masih ambigu antara orientasi pemberdayaan ekonomi masyarakat atau formalisasi agama demi kepentingan sepihak. 
Bagi penulis, sebuah kebenaran terletak pada aktifitas suatu proses pencarian dan partisipasi sebagaimana dalam permainan, misalnya sepak bola. Untuk itu, bagi insan akademik dan peneliti, penulis sarankan agar 'kebenaran' disini dipahami bukan sebagai produk akhir berupa kumpulan eksplanasi atau "bukti-bukti" yang telah baku, melainkan sebuah keterlibatan diri dalam rangka memahami dan menghayati nilai-nilai yang hanya bisa diraih melalui understanding dan kerja (language game). Dalam proses ini, subyek hilang ditelan oleh peraturan, spirit dan ritme permainan, sehingga kesemuanya ikut serta merasakan arti sebuah permainan, termasuk para penontonnya.

Begitu pula dalam membangun sistem perbankan islam yang betul-betul islami. Penulis sarankan kepada para praktisi dan pemerhati ekonomi (termasuk ekonomi-islam), agar pencapaian itu tidak hanya dilakukan setengah-tengah dengan membedakan mana sunyek dan objek. Di samping itu, dengan didasari sikap analitis-kritis terhadap ekonomi islam akan mengantarkan kita pada keyakinan bahwa Islam memang rabmatan lil alamin. Karena, ekonomi islam adalah hasil tafsiran manusia atas Al qur'an dan As sunnab sehingga nilai kebenarannya tidak mutlak.

Selanjutnya, kepada pemerintah sebagai peletak-kebijakan dan masyarakat sebagai sasaran-kebijakan, di Indonesia, bank syariah yang telah lama diharapkan dan dibutuhkan, kini telah tumbuh dan berkembang sejak 25 tahun yang lalu. Tentu layak, bagi pemerintah mendukung penuh atas prakarsa besar para pemikir dan praktisi ekonomi dalam memperjuangkan mewujudkan bank syariah. Sedangkan bagi masyarakat, terutama umat islam, dukungan tersebut bisa berupa materi dengan menjadi nasabah dan mitra usaha, atau berupa konsep, pemahaman dan kritik yang bisa memacu perkembangan bank, agar bisa 'bermain' secara sportif dan enerjik dengan bank konvensional.

\section{DAFTAR PUSTAKA}

Abu Sa'ud, Mahmud, Garis-garis Besar Ekonomi Islam, Gema Insani Press, Jakarta : 1992

Ahmad, Zainal Abidin, H, Negara Adil Makmur Menurut Ibnu Siena, Bulan Bintang, Jakarta : 1974, Cet. 1

Antonio, Muhammad Syafi'i, Bank syariah : Dari Teori ke Praktek, Gema Insani Press, Jakarta : 2001, Cet. 1

As Shadr, Muhammad Baqir, Ekonomi Islam : Kenyataan atau Khayalan?, Jurnal AlHikmah, No. 4 Nop.1991-Feb. 1991

Bank Indonesia - PPBEI-FE Unibraw, Laporan Penelitian, "Potensi, Refrensi dan perilaku Masyarakat Terbadap Bank syariah : Studi di Wilayah Jawa Timur", 2000 
Bank Indonesia Direktorat Penelitian dan Pengaturan Perbankan, Ring-kasan Pokok-pokok. Hasil Penelitian 'Potensi, Refrensi dan Masyarakat Terbadap Bank syariah di PulauJawa",bi.go/bank_indonesia2/utamapublikasi/upload/BPSRingkasan. Penelitian. Pdf, Desember 2000

Chapra, M. Umer, Dr., Al Qur'an Menuju Sistem Moneter yang Adil, Dana Bakti Primayasa, Jakarta : 1997

Chapra, M. Umer, Dr., Islam dan Pembangunan Ekonomi, Gema Insani Perss, Jakarta : 2000

Chapra, M. Umer, Dr., Islam dan Tantangan Ekonomi, Islamisasi Ekonomi Kontemporer, Tim Risalah Gusti (penerj.), Risalah Gusti, Surabaya, : 1999, Cet. 1

Departeman Agama, Al Qur'an dan Terjemahannya, Yayasan Penyelenggara Penterjemah Al Qur'an, PT. Bumi Restu, Jakarta : 1975

Harian Umum Kompas, Pembiyaan Bank syariah, 90 Persen untuk UMKM, 31 Mei 2003

Hidayat, Komaruddin, Dr., Memahami Bahasa Agama, Sebuab Kajian Hermeneutik, Paramadina, Jakarta : 1996, Cet. 1

Juliantara, D., Satu dari Nol, Memutar Roda Hidup, Memberi Makna pada Hidup, Asia Sedar, Panggungharjo : 2002, Cet. 1

Karim, Adiwarman Azwar, Ir., S.E., M.A., Ekonomi Islam, Suatu Kajian Kontemporer, Gema Insani Perss, Jakarta : 2001,

Karim, Adiwarman Azwar, Ir., S.E., M.A., Ekonomi Mikro Islam, the International Institute os Islamic Thought (IIIT) Indonesia, 2002, Cet. 1

Karim, Adiwarman Azwar, Ir., S.E., M.A.,Sejarah Pemikiran Ekonomi Islam, Tim IIT (penerj.), , the International Institute os Islamic Thought (IIIT) Indonesia, 2002, Cet . 2

Koran Republika, Pemahaman Masyrakat tentang Ekonomi Syariah Memprihatinkan, 19 Nopember 2002

Mannan, A., Prof., MA., Ph.D., Teori dan Praktek Ekonomi Islam, Dana Bakti Primayasa, Jakarta : 1997

Muhajir, Afifuddin, Membangun Nalar Islam Moderat: Kajian Metodologis, Tanwirul Afkar : Situbondo, 2018

Muhammad, Drs., M.Ag., (ed.) Bank Syari'ah ; Analisis Kekuatan, Kelemahan, Peluang dan Ancaman, Ekonisasi, Yogyakarta : 2002, Cet. 1

Rahardjo, M. Dwawam, Islam dan Transpormasi Sosial- Ekonomi, Lembaga Studi Agama dan Filsafat, Jakarta : 1999, Cet.1

Rahardjo, M. Dwawam, Islam dan Transpormasi Sosial- Ekonomi, Lembaga Studi Agama dan Filsafat, Jakarta : 1999, Cet.1

Stevenson, Leislie dan David L. Haberman, Sepulub Teori Hakikat Manusia, Yudi Santoso dan Sart Pasaribu (penerj.), Yayasan Bentang Budaya, Yogyakarta : 2001, Cet. 1 
Tim Penyusun, Insiklopedi Islam, PT. Ichtiar Baru Van Hoeve, Jakarta : 2002, Cet. 1

Usman, Rachmadi, SH., Aspek-aspek Hukum Perbankan Islam di Indonesia, PT. Citra Aditya Bakti, Bandung : 2002, Cet. 1

bttp:/ / ekonomi.kompas.com/ read/2017/04/28/173602626/februari.2017.aset.indust ri.kenangan.syariah.capai.rp.897.1.triliun 